\title{
Projecting Impacts of Fire Management on a Biodiversity Indicator in the Sierra Nevada and Cascades, USA: The Black-Backed Woodpecker
}

\author{
Dennis C. Odion ${ }^{1,2}$ and Chad T. Hanson ${ }^{*}, 3$ \\ ${ }^{1}$ Earth Research Institute, University of California, Santa Barbara, California, CA 93106, USA \\ ${ }^{2}$ Department of Environmental Studies, Southern Oregon University, Ashland, Oregon, OR 97520, USA \\ ${ }^{3}$ Earth Island Institute, 2150 Allston Way, Suite \#460, Berkeley, CA 94704, USA
}

\begin{abstract}
In the Sierra Nevada and southern Cascade ranges of California and Oregon, a genetically distinct population of the black-backed woodpecker has become rare due, in part, to fire suppression. This species is considered an indicator species for its primary habitat: early successional burned forests with an abundance of standing dead trees. Fuel reduction treatments such as post-fire logging, and forest thinning prior to fire (by creating insufficient snag density and enhancing fire suppression), may further reduce this habitat, but this has not been quantified. Our goal here is to address this information gap. Specifically, we first quantified the impacts of fire suppression and fuel treatments on primary habitat for the black-backed woodpecker. Our objective in this paper was to address how fire management affects the primary habitat of the black-back woodpecker and associated species in the Sierra Nevada and Cascades. We found that fire suppression was associated with a dramatic reduction in stand-initiation processes, a proxy for tree mortality, since the 1930s on public lands. We additionally found that thinning and post-fire clear cutting each exacerbated the effects of fire suppression by reducing primary habitat at an approximately 1:1 ratio with area treated. A scenario based on thinning 20 percent of mature forests over a 20 year period, and post-fire logging in $33 \%$ of potential habitat created by fire, reduced the amount of primary habitat after 27 years to $30 \%$ of the amount that would occur without these treatments, assuming that modeled effects of the fuel treatments in controlling fire may be realized. Our results indicate that conserving the distinct population of black-backed woodpeckers in the southern Cascades and Sierra Nevada and the biodiversity for which they are an indicator will require that more unthinned area be burned by wildfires and protected after fire as critical habitat. Our results also show that restoration of fire to an extent closer to historical levels would considerably increase black-backed woodpecker habitat and have minimal tradeoff with conservation of mature forest.
\end{abstract}

Keywords: Black-backed woodpecker, burned forest habitat, fire specialist, fire suppression, forest thinning, post-fire logging, snag basal area.

\section{INTRODUCTION}

There may be no forest bird in western North America more restricted to a single vegetation condition than the black-backed woodpecker (Picoides arcticus) is to forests of relatively dense fire-killed trees [1-3], where its primary prey, wood-boring beetles, are available in sufficient numbers to offset energy costs of foraging [4, 5]. The woodpecker's reliance on this fire-specialized insect prey in montane forests makes the habitat needs of the bird exceptionally narrow [2, 6, 7]. In fact, despite extensive surveys, only three black-backed woodpecker territories have been documented in unburned forests in California and Oregon in the literature [8], and nest density surveys conducted in both burned forest and nearby unburned forest found numerous nests in post-fire habitat but none in unburned forest [9]. Most black-backed woodpecker detections in the Sierra Nevada and Cascades have been from forests having at least $20 \mathrm{~m}^{2} /$ ha basal area of snags $>23$

*Address correspondence to this author at the Earth Island Institute, 2150 Allston Way, Suite \#460, Berkeley, CA 94704, USA; Tel: 530-273-4585;

E-mail: cthanson1@gmail.com $\mathrm{cm}$ diameter at breast height [10-12] that burned within the previous 7 years [13]. This habitat, which we refer to as primary habitat, must be constantly replenished across the landscape.

Whether the black-backed woodpecker could survive for many generations in the southern Cascades and Sierra Nevada without its primary habitat is questionable. Blackbacked woodpecker territories with lower snag basal area have far larger home ranges than those with levels near or above the mean, and travel more than twice the distance to seek food that is less abundant, relative to burned forest [10]. Consistent with conservation biology principles, larger home ranges are indicative of birds that are working much harder, and expending far more energy, in order to obtain food, corresponding to lower reproduction and survival levels that are associated with non-viable "sink" populations [14, 15]. Thus, the long-term viability of the black-backed woodpecker likely depends on its primary habitat even though habitat with fewer snags may sometimes be used.

The black-backed woodpecker is also a U.S. Forest Service indicator of the status and trends of biodiversity associated with its primary habitat. Furthermore, the black- 
backed woodpecker plays a key role in forest ecology by providing nesting holes in fire killed trees for other cavitynesting birds and mammals [5, 16]. These nesting cavities may have a long lifespan in standing dead trees, linking the fire that originally created black-backed woodpecker habitat to the long-term availability of critical resources for reproduction among many species. Thus, maintaining primary habitat for the black-backed woodpecker is important for overall diversity in forested landscapes.

Pierson et al. [17], in a genetic analysis of black-backed woodpeckers from blood and feather samples, found that the allopatric eastern Oregon Cascades population is genetically distinct from the Rockies/boreal population. Pierson et al. [17] concluded that the extent of the genetic distinction between these two populations was "similar to those documented among subspecies" in other birds occupying similar ranges. Pierson et al. [17] did not collect genetic samples from the California population of black-backed woodpeckers. Further study is warranted to clarify the relationship of the population in California, which may also be disjunct to some degree with the eastern Oregon Cascades population, and is disjunct with other populations of the species. However, it appears that the population in the Sierra Nevada and Oregon Cascades is genetically distinct from other black-backed woodpecker populations, similar to the distinction between the northern spotted owl in the Pacific Northwest, a subspecies of Strix caurina that is listed as threatened $[18,19]$, and the California subspecies, which is not listed. Therefore, in addition to the biodiversity for which it serves as an indicator or provides vital resources for reproduction, the black-back woodpecker is an important conservation concern in its own right in the Sierra Nevada and southern Cascades.

Historical accounts by Cooper in 1870 [20] described black-backed woodpeckers as "numerous" in the Sierra Nevada and southern Cascades. They are now considered rare due to fire suppression and logging [21, 22]. On December 15, 2011, the California Fish and Game Commission accepted for consideration the petition submitted to list the black-backed woodpecker as threatened or endangered. This action has resulted in this species receiving the interim designation of "candidate species." Under the California Endangered Species Act, candidate species are protected against habitat removal by state agencies. On May 2, 2012, the Sierra Nevada and eastern Oregon Cascades population was petitioned for listing as threatened or endangered under the federal Endangered Species Act [23]. On April 8, 2013, the United States Fish and Wildlife Service issued a positive preliminary finding on the petition, concluding that listing this black-backed woodpecker population may be warranted.

Treatments to reduce forest fuels in the Sierra Nevada and southern Cascades may remove large areas of primary habitat for the black-backed woodpecker $[1,3,11]$. The most obvious example is the harvesting of burned trees in which the woodpeckers nest and upon which they forage. A less obvious example is the thinning of unburned forests. This can impact black-backed woodpecker habitat by substantially reducing forest density and, therefore, snag availability should fire occur [2]. In addition, forest thinning is often done to improve fire suppression capabilities to better contain wildfires $[24,25]$. It has been projected that such fuel treatments, if strategic, may reduce wildfires by 50 percent $[24,26]$, which would exacerbate existing fire suppression impacts on black-backed woodpeckers.

To date, there have been no systematic analyses of fire management impacts to the primary habitat of the blackbacked woodpecker in the Sierra Nevada and southern Cascades. Our primary objective here is to address this information gap. Specifically, we quantified the impacts of fire suppression and fuel treatments on primary habitat for the black-backed woodpecker. To address fire suppression, we considered how rates of stand-initiation, a proxy for tree mortality, have changed since fire suppression became effective. To address current fuel treatments, we quantified future burned habitat with and without thinning and post-fire logging and a $50 \%$ improvement in the efficacy of fire suppression. Secondly, we considered how mature forest would change in area under the same management scenarios we considered for black-backed woodpeckers. This provides an opportunity to test how the habitat needs of species at opposite ends of the successional spectrum may be balanced by ongoing fire management.

\section{METHODS}

\section{Study Area}

To define the study area we used the National Geographic range map for the black-backed woodpecker [27]. Within this area we included all conifer forest types where the woodpecker may nest in the Sierra Nevada and Cascades, from mixed-conifer forest and eastside pine up to subalpine forests at the highest elevations [28] on public lands. The analysis area defined by these criteria for the black-backed woodpecker population in the Sierra Nevada, southern Cascades of California, and eastern Oregon Cascades included $36,652 \mathrm{~km}^{2}$ of middle/upper montane, and subalpine, forested landscape on federal lands in these regions. Our analysis of habitat change focused only on the public lands within this area. This is because potential habitat for black-backed woodpeckers and other species for which it serves as an indicator is typically logged immediately following fire on private lands. Therefore, the habitat is currently restricted almost entirely to public lands.

\section{Data on Stand-Initiation and Forest Regrowth}

An estimate of the impacts of fire suppression on the availability of primary habitat for the black-backed woodpecker may be obtained by comparing the rates of stand-initiation immediately before and after the onset of fire suppression. To accomplish this, we used the extensive U.S. Forest Service Forest Inventory and Analysis (FIA) forest monitoring data (http://www.fia.fs.fed.us/tools-data/). FIA is a monitoring system based on one permanent, random plot per 2400 ha across all forest lands. We excluded plots from non-conifer and lower montane areas [13]. We included plots for all conifer forest types (but not pinyon-juniper, which is apparently not used by black-backed woodpeckers [13]) from montane through subalpine forest types along an elevational gradient $[13,28]$. These included plot types dominated by the following: ponderosa pine (Pinus 
ponderosa); sugar pine (Pinus lambertiana); white fir (Abies concolor); grand fir (Abies grandis); Douglas-fir (Pseudotsuga menzeisii); incense cedar (Calocedrus decurrens); western red cedar (Thuja plicata); mixed conifer (pine and fir); western hemlock (Tsuga heterophylla); Engelmann spruce (Picea engelmanii); Pacific silver fir (Abies amabilis); red fir (Abies magnifica); noble fir (Abies procera); Jeffrey pine (Pinus jeffreyi); lodgepole pine (Pinus contorta); western white pine (Pinus monticola); mountain hemlock (Tsuga mertensiana); whitebark pine (Pinus albicaulis); foxtail pine (Pinus balfouriana); limber pine (Pinus flexilis); and subalpine fir (Abies lasiocarpa). FIA data were available from 2001-2009, comprising $90 \%$ of the plots available within our analysis regions. There were a total of 641 FIA plots in the database that met our criteria. We eliminated plots which had multiple stand-initiation dates.

An FIA plot consists of a 1 ha area. For tree measurements, this area is sub-sampled with four circular subplots that are 0.1 ha for large tree sampling and 0.017 ha for smaller tree sampling (defined by region). The diameter at breast height (dbh) and crown position of each tree and the ring count from two cores from dominant and co-dominant trees of each conifer species are measured in each subplot [29]. Stand age for an FIA plot is determined from the average of all ring counts from sub-plot samples, weighted by cover of sampled trees, and 8 years are added for estimated time to grow to breast height $(1.4 \mathrm{~m})$ [29]. We used FIA plots classified as forested. As described below, we used regression analysis of tree basal area as a function of stand age to determine existing rates of forest redevelopment following stand-initiating fire.

\section{Contemporary Rates of Primary Habitat Formation}

To define the current rate of formation of primary blackbacked woodpecker habitat across this region, we analyzed fire disturbances using all available processed U.S. government "Monitoring Trends in Burn Severity" (MTBS) data from 1984-2010 in the study area (www.mtbs.gov). We classified the data using a Relative delta Normalized Burn Ratio (RdNBR) threshold $>574$, as described by Miller and Thode [30]. At RdNBR of 574, mean basal area mortality of about $51 \%$ on average occurs among trees $>30 \mathrm{~cm}$ in diameter at breast height [31]. Therefore, for RdNBR values $>574$, mean basal area mortality for trees selected by blackbacked woodpeckers ranged from 51-100\% [31]. From fire severity data we calculated rotation for fire having this range of mortality, which we call higher severity fire [32].

\section{Statistical Analyses}

We used live tree diameter at breast height (dbh) data to prepare regressions with basal area and stand age, and used stand age data from the unmanaged forest landscape (areas in which stand age is a function of natural disturbance, rather than logging) to derive the existing stand age distribution and evaluate it relative to the theoretical distribution in the absence of fire suppression. Unmanaged forests included those in designated wilderness, inventoried roadless areas, national parks, and wild and scenic river corridors. To better understand the degree to which fire versus insect and disease disturbances may naturally account for habitat for the blackbacked woodpecker, we plotted the FIA stand ages and compared rates of stand initiation that occurred prior to and after fire suppression. This provides insight into the degree to which stand scale disturbances were caused by fire. A small decrease in amounts of stand initiation with fire suppression would suggest that disturbances other than fire have been important causes of forest mortality, while a large decrease would suggest that fire has been the predominant disturbance agent.

\section{Quantifying Future Habitat}

We calculated the annual rate of higher severity fire in mature and young forests and subsequent regrowth to parameterize our calculations using annual time steps to project future proportions of burned forest habitat $(\mathrm{H})$ along with mature forest $(\mathrm{M})$, young forest $(\mathrm{Y})$, non-habitat $(\mathrm{N})$, and thinned forest $(\mathrm{T})$. The proportion of each state in the landscape at time $t$ defined a vector $\left(P_{t}^{M}, P_{t}^{H}, P_{t}^{N}, P_{t}^{Y}, P_{t}^{T}\right)$. Transition probabilities $\psi_{t}^{\mathrm{rs}}$ equaled the probability that any portion of state $r$ at time $t$ transitions to state $s$ at time $t+1$ :

$\left[\begin{array}{lllll}\psi_{t}^{\mathrm{MM}} & \psi_{t}^{\mathrm{HM}} & \psi_{t}^{\mathrm{YM}} & \psi_{t}^{\mathrm{TM}} & \psi_{t}^{\mathrm{NM}} \\ \psi_{t}^{\mathrm{MH}} & \psi_{t}^{\mathrm{HH}} & \psi_{t}^{\mathrm{YH}} & \psi_{t}^{\mathrm{TH}} & \psi_{t}^{\mathrm{NH}} \\ \psi_{t}^{\mathrm{MY}} & \psi_{t}^{\mathrm{HY}} & \psi_{t}^{\mathrm{YY}} & \psi_{t}^{\mathrm{TY}} & \psi_{t}^{\mathrm{NY}} \\ \psi_{t}^{\mathrm{MT}} & \psi_{t}^{\mathrm{HT}} & \psi_{t}^{\mathrm{YT}} & \psi_{t}^{\mathrm{TT}} & \psi_{t}^{\mathrm{NT}} \\ \psi_{t}^{\mathrm{MN}} & \psi_{t}^{\mathrm{HN}} & \psi_{t}^{\mathrm{YN}} & \psi_{t}^{\mathrm{TN}} & \psi_{t}^{\mathrm{NN}}\end{array}\right]\left[\begin{array}{c}\mathrm{P}_{t}^{\mathrm{M}} \\ \mathrm{P}_{t}^{\mathrm{H}} \\ \mathrm{P}_{t}^{\mathrm{Y}} \\ \mathrm{P}_{t}^{\mathrm{T}} \\ \mathrm{P}_{t}^{\mathrm{N}}\end{array}\right]=\left[\begin{array}{c}\mathrm{P}_{t+1}^{\mathrm{M}} \\ \mathrm{P}_{t+1}^{\mathrm{H}} \\ \mathrm{P}_{t+1}^{\mathrm{Y}} \\ \mathrm{P}_{t+1}^{\mathrm{T}} \\ \mathrm{P}_{t+1}^{\mathrm{N}}\end{array}\right]$

Fig. (1) shows the relationship between the states and non-zero transition probabilities.

The initial amount of mature forest was the proportion of FIA plots with $>20 \mathrm{~m}^{2} / \mathrm{ha}$ basal area. Initial amounts of burned habitat $(\mathrm{H})$ and non-habitat $(\mathrm{N})$ were determined by the amount created by higher-severity fire in mature forests (M) in 7 years using the rate of higher-severity fire from 1984-2010. The initial proportion of young forests (Y) was determined by subtracting the proportions of mature forest $(\mathrm{M})$, burned habitat $(\mathrm{H})$ and non-habitat $(\mathrm{N}$ : burned but with snag basal area $<20 \mathrm{~m}^{2} / \mathrm{ha}$ ) from 1.0. The initial amount of thinned forest $(\mathrm{T})$ was considered zero for simplicity and because of lack of data. We used the transition rates in Table 1 and equation 1 to project 27 years forward, seven years after all thinning treatments would be completed. This represents the effect on primary habitat, during the 7-year period in which primary habitat persists [13], following full implementation of $20 \%$ thinning treatments over 20 years.

In fires in which there is $51-100 \%$ basal area mortality, not all forests would become black-backed woodpecker habitat because some would be too sparse. We estimated the amount of forest that would be converted to primary habitat for black-backed woodpeckers, and biodiversity for which they serve as indicators, by determining the proportion of FIA plots with $>20 \mathrm{~m}^{2} /$ ha live basal area $\left(D_{75}\right)$ that would have $>20 \mathrm{~m}^{2} /$ ha following higher severity fire, assuming an 


\section{Black-backed Woodpecker habitat model}

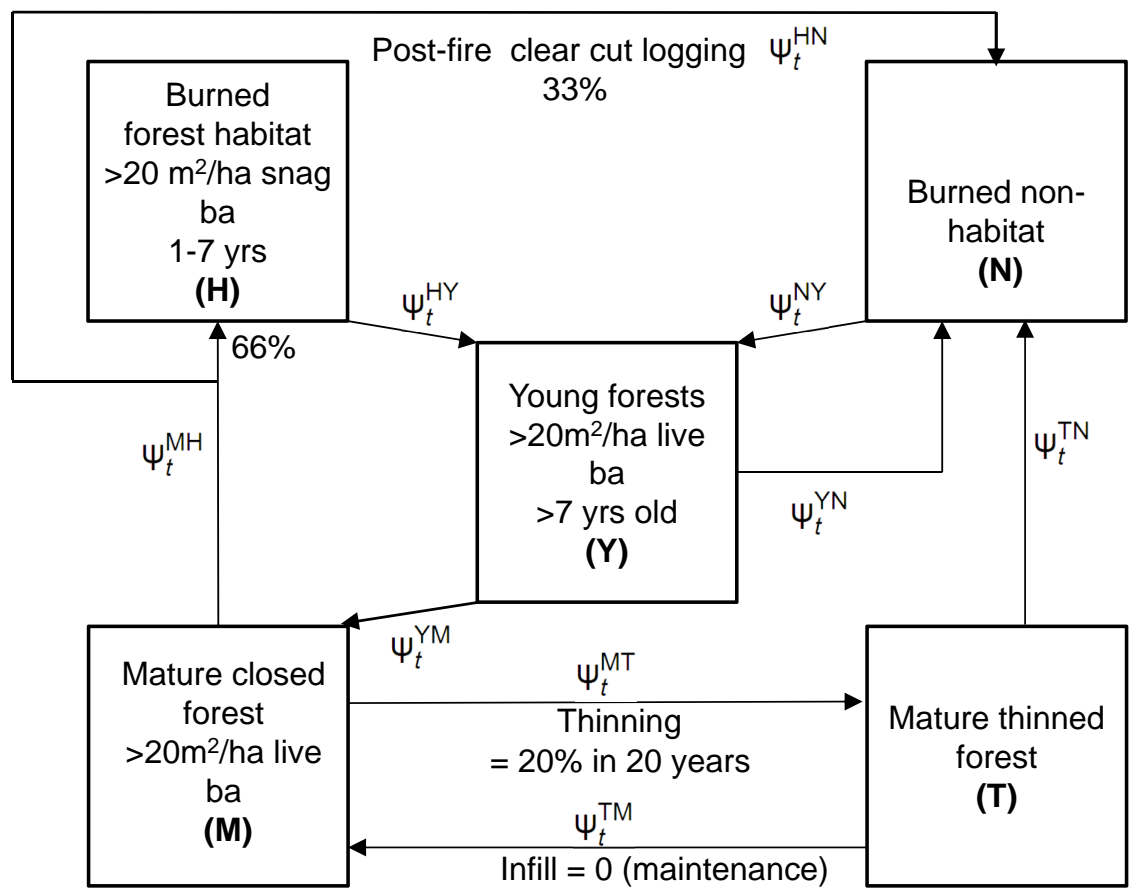

Fig. (1). State and transition model for projecting future amounts of black-backed Woodpecker habitat. Transitions that do not occur, such as between burned habitat and thinned forest, are not shown. All transitions and their calculations are listed in Table $\mathbf{1}$.

average mortality of $75 \%$ of basal area (i.e., the midpoint of the range of $51-100 \%$ basal area mortality in the fire severity data). Forests that would have $<20 \mathrm{~m}^{2} / \mathrm{ha}$ snag basal area after higher severity fire were considered not to function as primary habitat. The proportions $\left(\mathrm{D}_{75}\right.$ and $\left.1-\mathrm{D}_{75}\right)$ were multiplied with the annual rotation of higher severity fire to determine the transition rate for primary habitat and nonhabitat created by fire ( $\psi_{t}^{\mathrm{M} H}$ and $\psi_{t}^{\mathrm{MN}}$ respectively (Table $\left.\mathbf{1}\right)$ ).

Forests with very high basal area could also burn with RdNBR values $<574$ and yield snag basal area $>20 \mathrm{~m}^{2} / \mathrm{ha}$. However, we found that this would be $<1 \%$ of the amount created by higher severity fire. We therefore did not consider effects of lower severity fire in creating primary habitat. We also did not include unburned areas with higher levels of recent tree mortality from native beetles as suitable habitat in this analysis because they have so rarely been found to function as habitat [8] and no existing data sets track and quantify the basal area of recently killed trees, but aerial monitoring data does indicate that less than one-tenth of $1 \%$ of the unburned forest in the study region might qualify as primary habitat, based upon snag densities (http://www.fs .usda.gov/detail/r5/forest-grasslandhealth/?cid=fsbdev3_046677).

We defined the longevity of burned forest habitat $(\mathrm{H})$ to be 7 years after fire [13] and we considered the annual transition rate $\psi_{t}^{\mathrm{HY}}$ from burned habitat to the next forest state, young forest (Y), to be 1/7 (Table 1).

The transition from young forest to mature forest $\psi_{t}^{Y M}$ was defined by the amount of time after higher severity fire, starting at year 8 , needed for forests to develop $20 \mathrm{~m}^{2} / \mathrm{ha}$ live tree basal area (Table 1). Lower severity fire can reduce basal area from $>20 \mathrm{~m}^{2} /$ ha to $<20 \mathrm{~m}^{2} / \mathrm{h}$. However, this transition is already considered in the regrowth rate (i.e., it is the net rate), which incorporates the effects of lower severity fire. Therefore, transition from mature to young forest $\psi_{t}^{\mathrm{MY}}$ was zero. Young forest was assumed to burn with the same rate of higher severity fire as mature forests, so the rotation of higher severity fire provides the transition from young forest to non-habitat, $\psi_{t}^{\mathrm{YN}}$ (Table 1). We assumed that burned forest habitat $(\mathrm{H})$ and non-habitat $(\mathrm{N})$ do not reburn within 7 years of a previous fire. We also assumed that development of non-habitat $(\mathrm{N})$ to mature forest $(\mathrm{M})$ will take the same pathway and time as development of burned habitat $(\mathrm{H})$ to mature forest $(\mathrm{M})$. Additionally, there were a number of transitions that do not occur among states, which were assigned a transition probability of zero (e.g., burned habitat to thinned forest, $\psi_{t}^{\mathrm{H} T}$, Table 1), and are not shown in Fig. (1).

\section{Treatment Assumptions}

We quantified the effects of treatments over a 27-year period. The transition from mature to thinned forest, $\psi_{t}^{\mathrm{M} T}$, was calculated assuming strategic placement of thinning treatments in mature forests to help contain wildfires [26]. For our default scenario, thinning would impact $20 \%$ of the amount of the landscape that had mature forest $(69 \%)$ in each year, beginning in year 1. Treatment of $20 \%$ of the landscape has been shown in modeling studies to reduce wildfires by about 50\% [26]. Therefore, we also calculated the effect of doubling the length of the rotation of higher severity fire, $\mathrm{FR}^{\mathrm{hs}}$. 
Table 1. Annual Transition Probabilities Used in Transition Matrices for Each Scenario Analyzed for Forests Used by the BlackBacked Woodpecker in the Sierra Nevada, southern Cascades, and Eastern Oregon Cascades

\begin{tabular}{|c|c|c|c|}
\hline Transition Probabilities & No Treat & Thin $20 \%$ Maintain & Post-Fire Clearcut Recover \\
\hline$\psi_{t}^{\mathrm{M} M}$ & $1-\psi_{t}^{\mathrm{M} H}$ & $1-\psi_{t}^{\mathrm{M} H}-\psi_{t}^{\mathrm{M} T}$ & $1-\psi_{t}^{\mathrm{M} H}-\psi_{t}^{\mathrm{M} T}-\psi_{t}^{\mathrm{MN}}$ \\
\hline$\psi_{t}^{\mathrm{M} H}$ & $\left(1 / \mathrm{FR}^{h s}\right)^{*} \mathrm{D}_{75}$ & $\left(1 / \mathrm{FR}^{h s}\right) * \mathrm{D}_{75}$ & $\left(1 / \mathrm{FR}^{h s}\right) * \mathrm{D}_{75} * .67-.33\left(1 / \mathrm{FR}^{h s}\right)$ \\
\hline$\psi_{t}^{\mathrm{M} Y}$ & 0 & 0 & 0 \\
\hline$\psi_{t}^{\mathrm{M} T}$ & 0 & $.689 * 0.01$ & $.689 * 0.01$ \\
\hline$\psi_{t}^{\mathrm{MN} N}$ & $\left(1 / \mathrm{FR}^{h s}\right) *\left(1-\mathrm{D}_{75}\right)$ & $\left(1 / \mathrm{FR}^{h s}\right)^{*}\left(1-\mathrm{D}_{75}\right)$ & $\left(1 / \mathrm{FR}^{h s}\right)^{*}\left(1-\mathrm{D}_{75}\right)+.33\left(1 / \mathrm{FR}^{h s}\right)$ \\
\hline$\psi_{t}^{\mathrm{HM}}$ & 0 & 0 & 0 \\
\hline$\psi_{t}^{\mathrm{HH} H}$ & $1-\psi_{t}^{\mathrm{H} Y}$ & $1-\psi_{t}^{\mathrm{H} Y}$ & $1-\psi_{t}^{\mathrm{H} Y}$ \\
\hline$\psi_{t}^{\mathrm{H} Y}$ & $1 / 7$ & $1 / 7$ & $1 / 7$ \\
\hline$\psi_{t}^{\mathrm{H} T}$ & 0 & 0 & 0 \\
\hline$\psi_{t}^{\mathrm{HN}}$ & 0 & 0 & 0 \\
\hline$\psi_{t}^{\mathrm{YM}}$ & $1 /\left(\mathrm{G}^{Y M}-7\right)$ & $1 /\left(\mathrm{G}^{Y M}-7\right)$ & $1 /\left(\mathrm{G}^{Y M}-7\right)$ \\
\hline$\psi_{t}^{\mathrm{YY}}$ & $1-\psi_{t}^{\mathrm{Y} N}-\psi_{t}^{\mathrm{Y} M}$ & $1-\psi_{t}^{\mathrm{Y} N}-\psi_{t}^{\mathrm{Y} M}$ & $1-\psi_{t}^{\mathrm{Y} N}-\psi_{t}^{\mathrm{Y} M}$ \\
\hline$\psi_{t}^{\mathrm{YT} T}$ & 0 & 0 & 0 \\
\hline$\psi_{t}^{\mathrm{YH}}$ & 0 & 0 & 0 \\
\hline$\psi_{t}^{\mathrm{Y} N}$ & $1 / \mathrm{FR}^{h s}$ & $1 / \mathrm{FR}^{h s}$ & $1 / \mathrm{FR}^{h s}$ \\
\hline$\psi_{t}^{\mathrm{T} M}$ & 0 & 0 & 0 \\
\hline$\psi_{t}^{\mathrm{TH} H}$ & 0 & 0 & 0 \\
\hline$\psi_{t}^{\mathrm{TY}}$ & 0 & 0 & 0 \\
\hline$\psi_{t}^{\mathrm{T} T}$ & 0 & 0 & 0 \\
\hline$\psi_{t}^{\mathrm{TN}}$ & 0 & 0 & 0 \\
\hline$\psi_{t}^{\mathrm{N} M}$ & 0 & 0 & 0 \\
\hline$\psi_{t}^{\mathrm{N} H}$ & 0 & 0 & 0 \\
\hline$\psi_{t}^{\mathrm{NY}}$ & $1 / 7$ & $1 / 7$ & $1 / 7$ \\
\hline$\psi_{t}^{\mathrm{N} T}$ & 0 & 0 & 0 \\
\hline$\psi_{t}^{\mathrm{NN}}$ & $1-\psi_{t}^{N Y}$ & $1-\psi_{t}^{N Y}$ & $1-\psi_{t}^{N Y}$ \\
\hline
\end{tabular}

Variables are as follows: $\mathrm{FR}^{\mathrm{hs}}$ is the higher severity fire rotation; $\mathrm{G}$ is the time required for stands to grow from young forest to mature forest; $\mathrm{D}_{75}$ is the proportion of FIA plots that had $>20 \mathrm{~m}^{2} /$ ha dead basal area after burning by assuming $50-100 \%$ basal area mortality (mean of $75 \%$ ); $\mathrm{H}=$ habitat (recently burned forest, 7 years or less post-fire, with $>20 \mathrm{~m}^{2} / \mathrm{ha}$ snag basal area); $\mathrm{Y}=$ young forest; $\mathrm{M}=$ Mature forest $(68.9 \%$ of landscape initially); and $\mathrm{N}=$ non-habitat.

We assumed that thinning treatments would be maintained and therefore the transition from thinned forest to mature forest, $\psi_{t}^{\mathrm{TM}}$, equaled 0 . We also assumed that no black-backed woodpecker primary habitat would be created by fire in thinned forests, $\psi_{t}^{\mathrm{TH}}=0$, and that thinned forests would remain in the same state following fire $\left(\psi_{t}^{\mathrm{TN}}=0\right)$ (Table 1).

For scenarios involving post-fire clear cutting, we assumed that $33 \%$ of the burned habitat would be affected in year 1 after fire. This may be lower than current rates [22], as much of the forests with higher basal area favored by black-backed woodpeckers are also targeted for harvest. The 
clear cutting was assumed to cause transition to non-habitat $[1,33]$.

Finally, we quantified the effect of both shortening and lengthening the current rotation of higher severity fire on mature forest habitat relative to burned forest habitat on the landscape. For both mature forest habitat and black-backed woodpecker primary habitat, the amount maintained under different rotations of higher severity fire can be expressed as a percentage of the maximum potential amount that could occur in 27 years. We used the equations in Table $\mathbf{1}$ to determine these maximum amounts. Potential mature habitat was determined as the amount with no fire occurring whatsoever in 27 years. One hundred percent of the potential habitat for black-backed woodpeckers was the amount when we increased the transition rate from mature forest to burned habitat to the same annual rate as burned habitat's transition back to mature forest. The same rate between these opposing processes would, over time, maintain the most black-backed woodpecker habitat.

\section{RESULTS}

\section{Stand-Initiation and Forest Regrowth}

Fig. (2) shows the current age classes from the FIA data of stands in the range of black-backed woodpecker in the unmanaged portions of the study area. The theoretical age class distribution in which fire suppression had never occurred has also been shown, using the rate of stand initiation from prior to fire suppression (from 1750-1850). The rate of stand-initiation prior to fire suppression was more than six times greater than the rate since 1930 (Fig. 2). This change in the stand-initiation rate has dramatically shifted the age class distribution of forests. There is a general absence of relatively young stands, indicating that, without fire, there are few disturbances leading to new stand

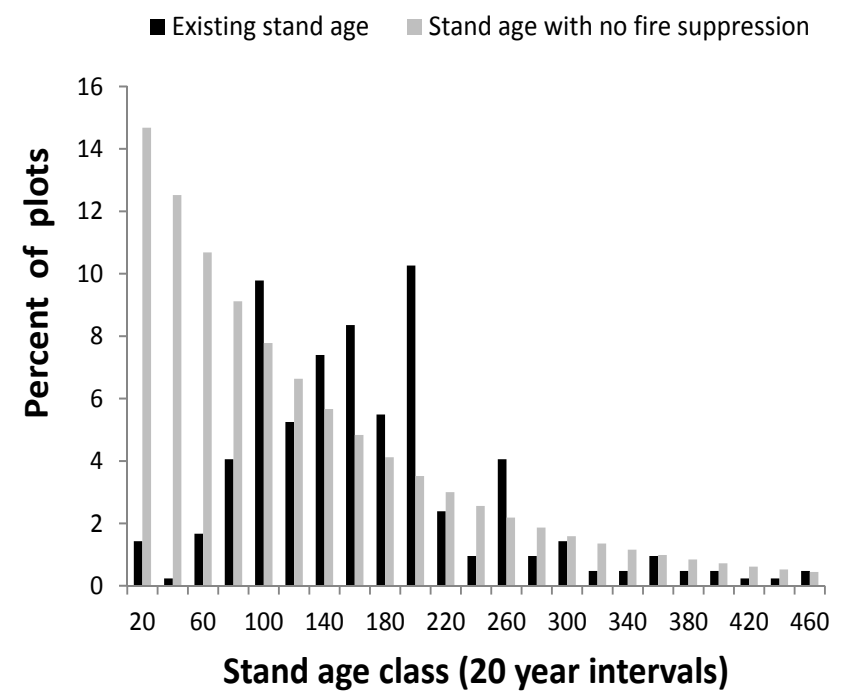

Fig. (2). Forest stand age distribution in the study area, and the theoretical distribution with a 126-year rotation for higher severity fire as occurred prior to settlement (1750-1850), based upon FIA stand age data. This pre-settlement rotation was calculated as 100 years divided by the proportion of plots with stand-initiation from 1750-1850 out of all plots with stand-initiation in or prior to 1850 . initiation. Thus the creation of habitat for the black-backed woodpecker appears to have been predominantly due to fire, because very little stand-initiation has occurred since the onset of fire suppression and the amount that has occurred may be explained by fires that escaped suppression.

There was a highly significant relationship in the FIA plots (managed and unmanaged areas combined) between live tree basal area and stand age (Fig. 3, $\mathrm{P} \ll 0.001, \mathrm{n}=$ 640 ). The amount of time following disturbance needed for forests to regrow late-successional live tree basal area of 20 $\mathrm{m}^{2} /$ ha was 94 years. The annual transition rate from young to mature forests, $\psi_{t}^{\mathrm{Y} M}$, was $1 /(94-7)$, with the 7 subtracted because 7 years of growth after fire were required for burned habitat to transition to young forests.

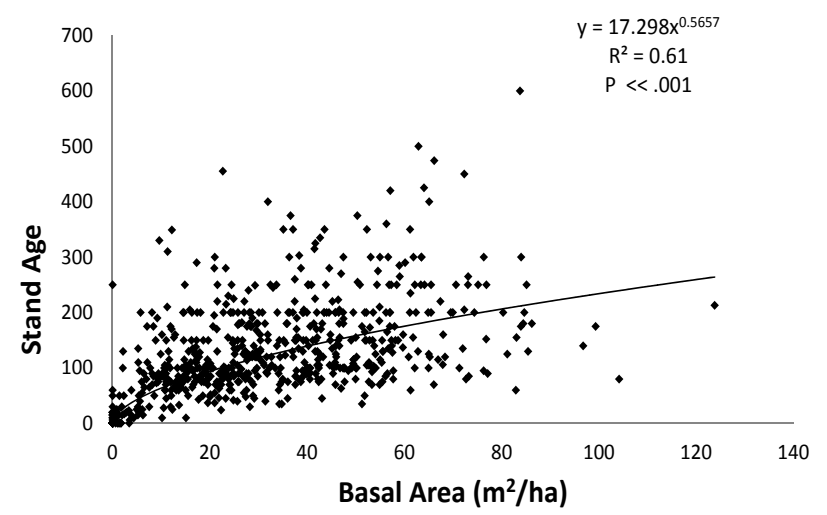

Fig. (3). Scatterplot of live tree basal area per hectare and stand age from U.S. Forest Service FIA data for the plots in the study area.

\section{Contemporary Rates of Primary Habitat Formation}

Using the U.S. government data, the rotation for higher severity fire (RdNBR >574) from 1984-2010 was 625 years over the entire analysis area. The amount of mature forest that had $>20 \mathrm{~m}^{2} /$ ha of snag basal area following higher severity fire in our projection (and thus became primary habitat), assuming 50-100\% basal area mortality (a mean of $75 \%$ basal area mortality), was $81 \%$. Thus, the annual transition rate from mature forest to primary habitat for black-backed woodpeckers, $\psi_{t}^{\mathrm{M} H}$, was $(1 / 625)^{*} 0.81$. With this low rate of primary habitat formation, this ephemeral habitat would remain at very low levels (less than $1 \%$ of the forested landscape on public lands within the range of this species in the eastern Oregon Cascades, southern Cascades in California, and Sierra Nevada) even without considering impacts from thinning or post-fire clear cutting (Table 2).

\section{Treatment Impacts}

With thinning of $20 \%$ of mature forests and assuming no effect of this on fire suppression, our calculations show, as would be expected, that there would be almost $20 \%$ less primary habitat than with no treatment after 27 years, or 7 years after the thinning treatments would be fully implemented (Table 2). A 50\% reduction in fire, as projected from strategically thinning $20 \%$ of the landscape to achieve enhanced fire suppression [24, 26], would increase the rotation interval for higher severity fire from 625 years to 
Table 2. Amounts of Black-Backed Woodpecker Primary Habitat Created by Higher Severity Fire in Forests 27 Years in the Future with No Treatments, Pre-Fire Thinning of 20 Percent of Mature Forests Over 25 Years, Post-Fire Clear-Cutting $33 \%$ of Habitat Created by Fire, Both Pre-Fire Thinning and Post-Fire Clear Cutting, and Both Pre-Fire Thinning and Post-Fire Clear Cutting with the Assumption that Pre-Fire Thinning Enhances Fire Suppression Effectiveness by 50 Percent

\begin{tabular}{|c|c|c|}
\hline & Habitat $\left.\mathbf{k m}^{2}\right)$ & Amount of the Habitat-Capable Public Landscape (\%) \\
\hline \hline No treatment & 243 & 0.66 \\
\hline Pre-fire thinning (20\%) & 205 & 0.56 \\
\hline Pre-fire thinning (20\%) with enhanced fire suppression & 107 & 0.29 \\
\hline Post-fire clear cutting (33\%) and no thinning & 184 & 0.50 \\
\hline $\begin{array}{c}\text { Pre-fire thinning (20\%) and post-fire clear cutting (33\%), } \\
\text { assuming no enhanced fire suppression }\end{array}$ & 137 & 0.20 \\
\hline $\begin{array}{c}\text { Pre-fire thinning (20\%) and post-fire clear cutting (33\%) } \\
\text { with enhanced fire suppression }\end{array}$ & 72 & 0.37 \\
\hline
\end{tabular}

1250 years. The effects can be seen in Fig. (4). The result of reduced fire, combined with the direct loss of habitat from thinning, would be a reduction of habitat by more than half after 27 years relative to no treatment (Table 2).

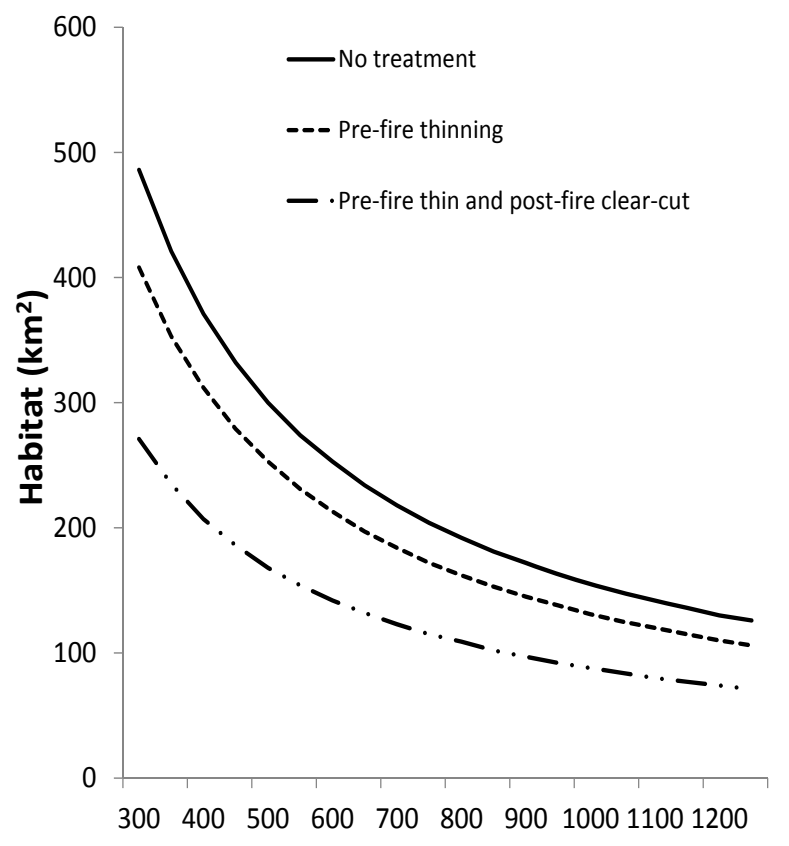

Higher severity fire rotation (years)

Fig. (4). Changes in amount of black-backed woodpecker primary habitat created by fire in the study area as a function of higher severity fire rotation under the following scenarios: no treatment; pre-fire thinning of $20 \%$ of mature forests; and pre-fire thinning combined with post-fire logging of $33 \%$ of habitat.

Post-fire clear cutting also removed habitat at a 1:1 ratio with area treated. Thus, the $33 \%$ treatment scenario resulted in $33 \%$ loss of primary habitat after 27 years compared to the no treatment scenario. In contrast to thinning, which takes 20 years for impacts to fully develop, post-fire clear-cutting would remove $33 \%$ of primary habitat from the start. The effects of both thinning and post-fire clear-cutting were approximately additive. With these treatments and no increase in fire suppression efficacy, after 27 years, nearly half the amount of primary habitat that would be maintained with no treatment would be eliminated (Table 2). If thinning succeeded in lengthening fire rotations to 1250 years (Fig. 4), the effects combined with clear cutting of $33 \%$ of postfire habitat would reduce overall primary habitat to $30 \%$ of the amount that would be maintained with no treatment (Table 2).

In contrast to burned habitat, the proportion of mature forest on the landscape remains relatively constant when higher severity fire increases (Fig. 5). This is because mature forest is maintained by regrowth. Mature forest amounts will remain relatively resilient and stable unless higher severity fire rotations shorten (more fire) to almost the length of the regrowth period for mature forests (94 years). At a rotation of 94 years, under which higher severity fire occurs at a level 6-7 times greater than current levels, mature forests would occupy $28,096 \mathrm{~km}^{2}$, or 77 percent of the landscape, and black-backed woodpecker primary habitat would occupy $1,361 \mathrm{~km}^{2}$, or 3.7 percent of the landscape, after 27 years.

\section{DISCUSSION}

The stand age data we analyzed indicate that fire has been and remains the predominant natural disturbance agent capable of creating most habitat for black-backed woodpeckers in the Sierra Nevada, southern Cascades of California, and eastern Oregon Cascades, and that there has been a paucity of disturbances leading to new stand initiation since the onset of fire suppression. Primary black-backed woodpecker habitat has thus declined dramatically: only $1 / 6^{\text {th }}$ as much has been created since the onset of fire suppression. This has been compounded by loss of habitat on private lands, where burned forests are typically logged. These factors likely explain how a bird that was historically somewhat common [20] has become rare.

Our calculations illustrate how impacts of current management further reduce habitat from levels that may be critically low already. Thinning and post-fire clear cutting (cutting most or all snags) reduced habitat at a 1:1 ratio with area treated. This makes it straightforward to infer the direct impacts of different amounts of these treatments than assumed in our default scenario. This 1:1 relationship between area treated and primary habitat lost also makes it straightforward to consider the effects of changing the 
definition of primary habitat. Most significantly, using our definitions of primary habitat, we found that thinning $20 \%$ of forests and post-fire clear-cutting 33\% of burned forests, along with $50 \%$ increased efficacy of fire suppression, would reduce future amounts of primary habitat for black-back woodpeckers, and the biodiversity for which they serve as indicators, to less than a third of the amount that would be maintained with no treatments.

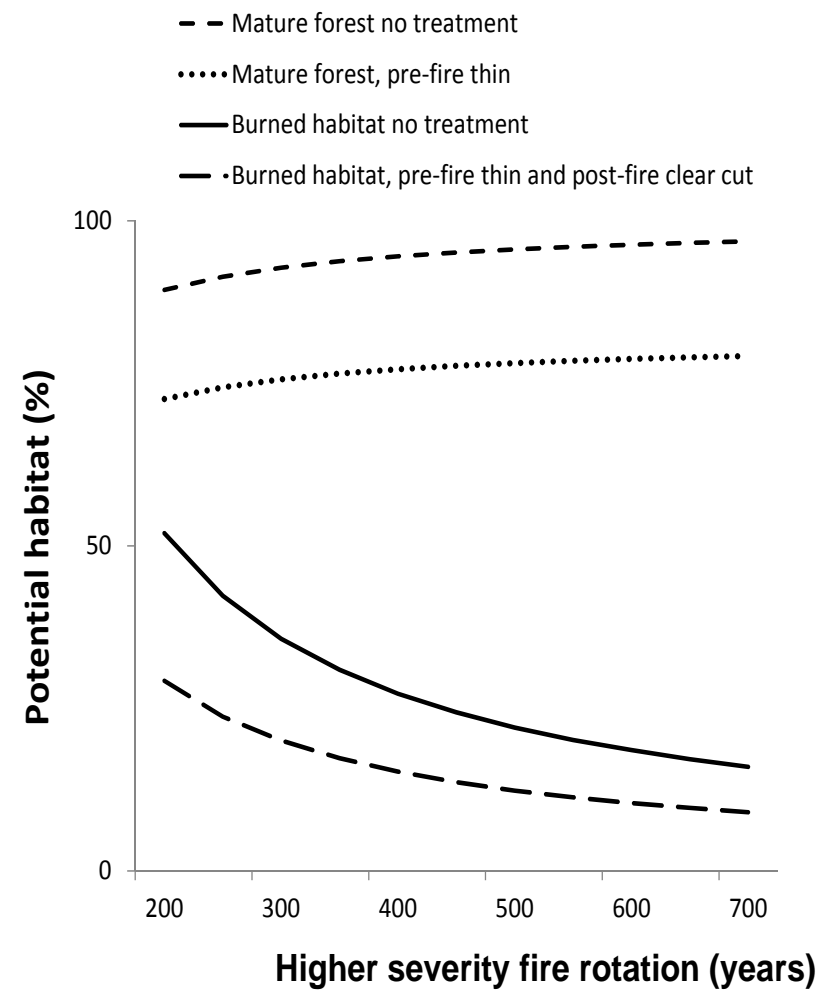

Fig. (5). Changes in the percent of maximum potential habitat for mature forest and black-backed woodpecker primary habitat created by fire in the study area as a function of higher severity fire rotation under the following scenarios: no treatment; pre-fire thinning of $20 \%$ of mature forests; and pre-fire thinning combined with postfire logging of $33 \%$ of habitat.

Our findings are only slightly affected if we relax the definition of primary habitat to include all mature forests burned with higher severity fire in the range of the blackbacked woodpecker (i.e., to include forests with $<20 \mathrm{~m}^{2} / \mathrm{ha}$ snag basal area). This is because most mature forests $(81 \%)$ have over $20 \mathrm{~m}^{2} /$ ha snag basal area after higher severity fire, so adding the more marginal forests has only a relatively small effect. Extending by 1-2 years the length of time burned forest serves as a primary habitat would also have only a minor effect on our findings. Shortening this time period 1-2 years would have a slightly larger effect in reducing primary habitat below levels we quantified than would lengthening it by the same amount of time. Data show relatively low, and greatly reduced, levels of use of burned forests by black-backed woodpeckers when more than five years have passed since fire relative to earlier post-fire years [13], so our estimates of primary habitat may be somewhat high. The main factor limiting the formation of habitat is lack of fire, which minimizes the effects of our specific definition of primary habitat.
Hanson et al. [23] have estimated that only several hundred black-backed woodpecker pairs may remain across the entire potential range of suitable habitat in California, and a lower number for the eastern Oregon Cascades. These population levels are substantially lower than average minimum viable populations for birds (3742 individual adults) estimated in the meta-analysis by Traill et al. [34]. The narrow habitat requirements of the black-backed woodpecker make it particularly vulnerable to further habitat loss. Because of fire suppression, burned habitat levels are not only lower, but availability maybe less predictable in time, with long gaps with little or no fire over large areas. Burned habitat may also be much more widely spaced geographically. This may be an important stressor because the maximum detection distance for black-backed woodpeckers for burned forests may be about $50 \mathrm{~km}$ [35]. Colonization of primary habitat may be prevented due to the lack of habitat nearby enough to provide a source of immigrants. Consistent with this possibility, extensive monitoring using both point counts and playback calls has failed to detect black-backed woodpeckers in over $40 \%$ of the larger mixed-severity fire areas containing suitable blackbacked woodpecker habitat in the Sierra Nevada, southern Cascades in California, and Modoc Plateau [13, 28].

Whether the population in California and the eastern Oregon Cascades remains viable may depend in significant part on the degree to which fuel treatments affect future fire, which has substantial potential to impact burned habitat amounts. However, it is important to recognize uncertainty in the projected effect of strategically treating $20 \%$ of the mature forested landscape. This is based on modeling projections, not empirical findings. Future fire is also uncertain due to climate change. However, rates of fire disturbances are so much lower than occurred prior to fire suppression (Fig. 2) that even a doubling of fire would still be far lower than the historic levels that once provided habitat for black-backed woodpeckers in California and Oregon. In addition, the prediction by Littell et al. [36] that fire will double by 2050 in the Pacific Northwest assumes decreased summer precipitation as a main driver of increased fire. Current data indicate a pattern of increasing, not decreasing, summer precipitation in the Pacific Northwest $[37,38]$. Other predictions suggest future variability in fire over the region, including increases as well as possible decreases in future fire [39]. In terms of actual patterns in fire occurrence under changing climate, there is no ongoing trend in the proportion of fire that is high in severity in the dry Cascades of Oregon [40, 41]; nor is there a trend in the amounts of high-severity fire in the southern Cascades of California [42], but data are only available since 1984. The upward trend in fire severity in the Sierra Nevada reported by Miller et al. [43] and Miller and Safford [44] using an incomplete regional data set does not exist when all the currently available burn severity data are analyzed, using the more comprehensive U.S. government fire severity data base from Monitoring Trends in Burn Severity, or "MTBS", and using forest mapping that pre-dates the time series to avoid missing montane conifer forest that experiences higher severity fire and is later remapped as chaparral [45]. While increased fire in the future could help prevent further habitat decline, under current management habitat may still be limited and ultimately insufficient in the future for black- 
backed woodpeckers and biodiversity for which they serve as indicators.

Although the number of black-backed woodpeckers has declined with suppression of fire, excess fire has been a concern for species that rely on mature forests. In the Sierra Nevada and southern Cascades, these include the spotted owl (Strix occidentalis ssp. occidentalis) and Pacific fisher (Martes pennanti). We calculated not only the percent of burned habitat, but also the percent of mature forest habitat that would occur with different rotations of higher severity fire after 27 years. Fig. (5) shows that the amount of mature forest is almost maximized at the current 625 year rotation for higher severity fire. It should be noted that not all of this mature forest would be habitat for all mature forest species; for example, spotted owls do not appear to nest in forests with less than 23-27 $\mathrm{m}^{2} /$ ha of basal area [46, 47]. Nonetheless, due to lack of fire, mature forest habitat, in areas where logging or fuel treatments has not diminished this habitat, may be available in amounts that may currently be near historical highs. Though doubling higher severity fire would have almost no effect on mature forests, it would increase habitat for black-backed woodpeckers substantially and would likely be the most effective way to increase populations above critically low levels. The best balance between the habitat needs of fire-dependent and mature forest species would be at higher rates of fire than those occurring today and closer to those that occurred before fire suppression. Because fire-dependent and mature forest dependent species are at opposite ends of the spectrum, most biodiversity is associated with a mosaic of these habitats, and balancing the habitat needs of these species will likely balance the needs for biodiversity in general [48, 49]. Moreover, emerging data indicate that, while mature forest species like the spotted owl select denser, unburned or lowseverity burned forest for nesting and roosting, they preferentially select higher severity fire areas (which have not been salvage logged) for foraging [50]. Thus, an increase from current low levels of higher severity fire may provide some overall benefits even to mature forest species.

\section{CONCLUSIONS}

Conserving the distinct population of black-backed woodpeckers in the Sierra Nevada, southern Cascades, and eastern Oregon Cascades, and the biodiversity for which this species is an indicator, may require that more unthinned area be burned by wildfires and protected after fire as critical habitat. Options for better conserving black-backed woodpeckers within the context of competing land management goals are reviewed in Bond et al. [51], and include recommendations to protect higher severity post-fire habitat in mature forests, as well as to curb thinning operations in unburned mature forest. Federal land management agencies have an opportunity to propose incorporation of these conservation recommendations into forest plans, which are currently commencing a process of revision. Importantly, our results show that restoration of fire to be closer to historical levels would considerably increase black-backed woodpecker habitat and have minimal tradeoff with conservation of mature forest.

\section{CONFLICT OF INTEREST}

The authors confirm that this article content has no conflict of interest.

\section{ACKNOWLEDGEMENTS}

We thank Tim Sinnott at Green InfoNetwork for the GIS work and the processing of the Forest Inventory and Analysis data for this manuscript, as well as the Environment Now foundation for their generous financial support of this work.

\section{REFERENCES}

[1] Hanson CT, North MP. Postfire woodpecker foraging in salvagelogged and unlogged forests of the Sierra Nevada. Condor 2008; 110: 777-82.

[2] Hutto RL. The ecological importance of severe wildfires: Some like it hot. Ecol Appl 2008; 18: 1827-34.

[3] Cahall RE, Hayes JP. Influences of postfire salvage logging on forest birds in the Eastern Cascades, Oregon, USA. For Ecol Manage 2009; 257: 1119-28.

[4] Murphy EC, Lehnhausen WA. Density and foraging ecology of woodpeckers following a stand-replacement fire. J Wildl Manage 1998; 62:1359-72.

[5] Dixon RD, Saab VA. Black-backed Woodpecker (Picoides arctcus), No. 509. In: Poole A, Gill F, Eds. Philadelphia, PA: The Birds of North America, Inc. 2000.

[6] Dudley JG, Saab VA. Home range size of Black-backed Woodpeckers in burned forests of Southwestern Idaho. West N Am Nat 2007; 67:593-600.

[7] Saab VA, Russell RE, Dudley JG. Nest-site selection by cavitynesting birds in relation to postfire salvage logging. For Ecol Manage 2009; 257: 151-9.

[8] Goggans R, Dixon RD, Seminara LC. Habitat use by three-toed and black-backed woodpeckers Deschutes National Forest, OregonL Oregon Department of Fish and Wildlife Nongame Program 1989.

[9] Russell RE, Saab VA, Rotella JJ, Dudley JG. Detection probabilities of woodpecker nests in mixed conifer forests in Oregon. Wilson J Ornithol 2009; 121:82-8.

[10] Siegel RB, Tingley MW, Wilkerson RL, Bond ML, Howell CA. Assessing home range size and habitat needs of black-backed woodpeckers in California: Report for the 2011 and 2012 field seasons. Point Reyes Station: Institute for Bird Populations. California; 2013.

[11] Hanson CT. Post-fire management of snag forest habitat in the Sierra Nevada. Ph.D. Dissertation. Davis, CA: University of California 2007.

[12] Saracco JF, Siegel RB, Wilkerson RL. Occupancy modeling of Black-backed woodpeckers on burned Sierra Nevada forests. Ecosphere 2011; 2: Article 31.

[13] Siegel RB, Tingley MW, Wilkerson RL. Black-backed woodpecker Management Indicator Species surveys on Sierra Nevada national forests. 2010 Annual Report. Point Reyes, CA: The Institute for Bird Populations [A report in fulfillment of U.S. Forest Service Agreement No. 08-CS-11052005-201, Modification \# 2] 2011.

[14] Carey AB, Horton SP, Biswell BL. Northern spotted owls: influence of prey base and landscape character. Ecol Monogr 1992; 62: $223-50$.

[15] Ward JP, Jr., Gutierrez RG, Noon BR. Habitat selection by Northern spotted owls: the consequences of prey selection and distribution. Condor 1998; 100:79-92.

[16] Tarbill GL. Nest site selection and influence of woodpeckers on recovery in a burned forest of the Sierra Nevada. Master's Thesis. Sacramento; California State University 2010.

[17] Pierson JC, Allendorf FW, Saab VA, Drapeau P, Schwartz MK. Do male and female Black-backed Woodpeckers respond differently to gaps in habitat? Evol Appl 2010; 3:263-78.

[18] Haig SM, Beever EA, Chambers SM, et al. Taxonomic considerations in listing subspecies under the U.S. Endangered Species Act. Conserv Biol 2006; 20 : 1584 - 94. 
[19] Funk W, Forsman ED, Mullins TD, Haig SM. Introgression and dispersal among spotted owl(Strix occidentalis)subspecies. Evol Appl 2008; 1: 161-71.

[20] Cooper JG. Ornithology of California: Land Birds. In: Baird SF. NY: Amo Press 1870 .

[21] Small A. California birds: their status and distribution. California: Ibis Publishing Company; 1974.

[22] Hanson CT, Cummings B. Petition to the State of California Fish and Game Commission to list the Black-backed Woodpecker (Picoides arcticus) as threatened or endangered under the California Endangered Species Act. [Unpublished document on file with the California Department of Fish and Game]; 2011.

[23] Hanson CT, Coulter K, Augustine J, Short D. Petition to list the Oregon/California and Black Hills populations of the black-backed woodpecker (Picoides arcicus) as threatened or endangered species and to designate critical habitat concurrent with listing. [Unpublished document on file with the U.S. Fish and Wildlife Service] 2012.

[24] Finney MA, Seli RC, McHugh CW, Ager AA, Bahro B, Agee JK. Simulation of long-term landscape-level fuel treatment effects on large wildfires. Int J Wildl Fire 2007; 16: 712-27.

[25] Collins BM, Stephens SL, Roller GB, Battles JJ. Simulating fire and forest dynamics for a landscape fuel treatment project in the Sierra Nevada. For Sci 2011; 57:77-88.

[26] Ager AA, Finney MA, Kerns BK, Maffei H. Modeling wildfire risk to northern spotted owl (Strix occidentalis caurina) habitat in central Oregon, USA. For Ecol Manage 2007; 246: 45-56.

[27] Dunn JL, Alderfer J. National Geographic field guide to the birds of North America. $5^{\text {th }}$ ed. Washington, D.C.: National Geographic Press 2006.

[28] Siegel RB, Wilkerson RL, Mauer DL. Black-backed Woodpecker (Picoides arcticus) surveys on Sierra Nevada national forests: 2008 pilot study. Point Reyes, CA; The Institute for Bird Populations, 2008.

[29] USDA. Field instructions for the annual inventory of California, Oregon, and Washington: Forest Inventory and Analysis Resource Monitoring and Assessment Program. Portland, OR: U.S.D.A. Forest Service, Pacific Northwest Research Station, 2010.

[30] Miller JD, Thode AE. Quantifying burn severity in a heterogeneous landscape with a relative version of the delta Normalized Burn Ratio (dNBR). Remote Sens Environ 2007; 109:66-80.

[31] Hanson CT, Odion DC, DellaSala DA, Baker WL. Morecomprehensive recovery actions for Northern Spotted Owls in dry forests: Reply to Spies et al. Conserv Biol 2010; 24:334-7.

[32] Williams MA, Baker WL. Spatially extensive reconstructions show variable-severity fire and heterogeneous structure in historical western United States dry forests. Glob Ecol Biogeogr 2012; DOI: 10.1111/j.1466-8238.2011.00750.x.

[33] Hutto RL, Gallo SM. The effects of postfire salvage logging on cavity-nesting birds. Condor 2006; 108:817-31.

[34] Traill LW, Bradshaw CJA, Brook BW. Minimum viable population size: a meta-analysis of 30 years of published estimates. Biol Conserv 2007; 139:159-66.

[35] Hoyt JS, Hannon SJ. Habitat associations of black-backed and three-toed woodpeckers in the boreal forest of Alberta. Can J For Res 2002; 32:1881-8.
[36] Littell JS, Oneil EE, McKenzie D, Hicke JA, Lutz JA, Norheim RA, Elsner MM. Forest ecosystems, disturbance, and climatic change in Washington State, USA. Clim Change 2010; 102: 12958.

[37] Mote PW. Trends in temperature and precipitation in the Pacific Northwest during the twentieth century. Northwest Sci 2003; 77:271-82.

[38] Hamlet AF, Mote PW, Clark MP, Lettenmaier DP. Twentiethcentury trends in runoff, evapotranspiration, and soil moisture in the western United States. J Climatol 2007; 20:1468-86.

[39] Krawchuk MA, Moritz MA, Parisien M, Van Dorn J, Hayhoe K Global pyrogeography: the current and future distribution of wildfire. PloS ONE 2009; 4: e5102.

[40] Schwind B (compiler). Monitoring trends in burn severity: report on the Pacific Northwest and Pacific Southwest fires (1984 to 2005). Sioux Falls, South Dakota: U.S. Geological Survey Center for Earth Resources Observation and Science, Available from http://www.mtbs.gov/reports/projectreports.htm; 2008.

[41] Hanson CT, Odion DC, DellaSala DA, Baker WL. Overestimation of fire risk in the Northern spotted owl recovery plan. Conserv Biol 2009; 23:1314-9.

[42] Miller JD, Skinner CN, Safford HD, Knapp EE, Ramirez CM. Trends and causes of severity, size, and number of fires in northwestern California, USA. Ecol Appl 2012; 22: 184-203.

[43] Miller JD, Safford HD, Crimmins MA, Thode AE. Quantitative evidence for increasing forest fire severity in the Sierra Nevada and southern Cascade Mountains, California and Nevada, USA Ecosystems 2009; 12:16-32.

[44] Miller JD, Safford HD. Trends in wildfire severity: 1984 to 2010 in the Sierra Nevada, Modoc Plateau, and southern Cascades, California, USA. Fire Ecol 2012; 8: 41-57.

[45] Hanson CT, Odion DC. Is Fire Severity Increasing in the Sierra Nevada Mountains, California, USA? In review in Intl J Wildl Fire.

[46] Pidgeon AM. Habitat characteristics of Northern spotted owls in the unmanaged forest of the Yakama Indian Reservation, eastern Washington. M.S. Thesis. Ellensburg: Central Washington University, 1995.

[47] Buchanan JB, Irwin LL, McCutchen EL. Within-stand nest site selection by spotted owls in the eastern Washington Cascades. J Wildl Manage 1995; 59: 301-10.

[48] Odion DC, Sarr DA. Managing disturbance regimes to maintain biodiversity in forested ecosystems of the Pacific Northwest. For Ecol Manage 2007; 246: 57-65.

[49] Swanson ME, Franklin JF, Beschta RL. et al. The forgotten stage of forest succession: early-successional ecosystems on forest sites. Front Ecol Environ 2011; 9:117-25.

[50] Bond ML, Lee DE, Siegel RB, Ward, JP, Jr. Habitat use and selection by California Spotted Owls in a postfire landscape. J Wildl Manage 2009; 73: 1116-24.

[51] Bond ML, Siegel RB, Craig DL, et al. A Conservation Strategy for the Black-backed Woodpecker (Picoides arcticus) in California. Version 1.0. Point Reyes Station: California: The Institute for Bird Populations and California Partners in Flight. 2012. 